University of Nebraska - Lincoln

DigitalCommons@University of Nebraska - Lincoln

2008

\title{
A New Species of Wockia Heinemann, 1890 (Lepidoptera: Urodidae) from Korea
}

Jae-Cheon Sohn

Department of Entomology, University of Maryland, College Park, MD 20742, U.S.A, jsohn@umd.edu

David Adamski

Department of Entomology, National Museum of Natural History, Smithsonian Institution, P.O. Box 37012, MRC 168, Washington, D.C., 20013- 7012, U.S.A., adamskid@si.edu

Follow this and additional works at: https://digitalcommons.unl.edu/systentomologyusda

Part of the Entomology Commons

Sohn, Jae-Cheon and Adamski, David, "A New Species of Wockia Heinemann, 1890 (Lepidoptera: Urodidae) from Korea" (2008). USDA Systematic Entomology Laboratory. 48.

https://digitalcommons.unl.edu/systentomologyusda/48

This Article is brought to you for free and open access by the Entomology Collections, Miscellaneous at DigitalCommons@University of Nebraska - Lincoln. It has been accepted for inclusion in USDA Systematic Entomology Laboratory by an authorized administrator of DigitalCommons@University of Nebraska - Lincoln. 


\title{
A NEW SPECIES OF WOCKIA HEINEMANN, 1890 (LEPIDOPTERA: URODIDAE) FROM KOREA
}

\author{
Jae-Cheon Sohn and David Adamski
}

(JS) Department of Entomology, University of Maryland, College Park, MD 20742, U.S.A (e-mail: jsohn@umd.edu); (DA) Department of Entomology, National Museum of Natural History, Smithsonian Institution, P.O. Box 37012, MRC 168, Washington, D.C. 20013-7012, U.S.A. (e-mail: david.adamski@ars.usda.gov)

Abstract. -Wockia koreana Sohn, n. sp., is described from Korea, representing the first record of Urodidae in eastern Asia. Biological and distributional data including host-plant records are provided. Photographs of the holotype and dimorphic antennal and hind tibial features are included in addition to illustrations of wing venation and male and female genitalia.

Key Words: Ditrysia, Urodoidea, taxonomy, biogeography, Salix

The Urodidae as currently defined (excluding Homadaula Lower 1899, Kyrki 1988) includes 59 species in three genera: Urodus Herrich-Schäffer, 1854, Spiladarcha Meyrick, 1913, and Wockia Heinemann, 1870. The family is most diverse in the Neotropics (Kyrki 1988). As evidence of the monophyly of Urodidae, Kyrki (1988) cited characteristics of the adults and larvae: lamellate antenna; a basal hair pencil on the male hindwing; long, slender larval prolegs with crochets in mesoseries; and on the larval 8th abdominal segment, the position of setae $\mathrm{L} 3$ ventroanterior to $\mathrm{L} 1$ and L2, and SV1 almost horizontal with $\mathrm{L} 3$. The relationship of Homadaula to Urodidae is questionable. Minet (1986), Kyrki (1990), Common (1990), Scoble (1992), and Kristensen and Skalski (1998) assigned the genus to Galacticidae, but Heppner (1998) included it within Urodidae.

The systematic position of Urodidae remains uncertain. Kyrki (1984) proposed that the family be removed from Yponomeutoidea but offered no further opinion on its placement. In subsequently defining Urodidae to include Wockia, Kyrki (1988) discussed its affinities with other superfamilies and noted several shared features with Schreckensteiniidae. However, he did not assign it to any superfamily. Nielsen (1989) first treated urodids as a separate superfamily, Urodoidea, and this assignment is widely accepted.

Wockia is the smallest genus of Urodidae, currently comprising only two species: $W$. asperipunctella (Bruand, 1852) from Europe and eastern North America and $W$. balikpapanella Kyrki, 1986 from Borneo. These are small moths with relatively dull color patterns. Kyrki (1988) provided generic features for Wockia and they include: labial palpi porrect, short, thickened medially with scales, blunt apically; antenna lamellate in the male, filiform in the female; chorda of forewing clearly visible; all radial, medial and anterocubital veins present and separate; uncus absent, with laterally lobed membranous structure; gnathos rudimentary; valva deeply di- 
vided terminally; costal lobe digitate; ovipositor telescopic; ductus bursae, dorsoventrally flattened, sclerotized; corpus bursae with two signa; larva with bisetose Af; and one puncture present on larval head.

The systematic position of Wockia has varied. The genus has been placed in both Yponomeutidae and Plutellidae (e.g., Leraut 1980, Zagulyaev 1989), but Kyrki (1988) considered it distinct from other yponomeutoid lineages and established the family Urodidae, including Urodus, Spiladarcha, and Wockia. Kyrki's hypothesis is accepted widely, although Fänger (1999) raised questions about the morphological homogeneity of Urodidae, noting that the transphragma of Wockia more resembles that of Epermeniidae than of Urodus.

Recent discoveries suggest that species richness in Wockia is under-studied. Two new species have been discovered in the Neotropics (D. Adamski et al., unpublished). Here we describe a new species from specimens found in the collection of Center for Insect Systematics, Gangwon National University, Korea, supplemented by an adult reared from larvae collected on the foliage of willow trees. This is the first record of Wockia from East Asia.

Pinned specimens and slide preparations were examined using dissecting and compound microscopes. Dissections of the male and female genitalia were prepared following Clarke (1941), except chlorazol black and mercurochrome were used as stains. Terminology follows Klots (1970) for genitalia and Forbes (1948) for wing venation. All label data are given verbatim within quotations.

\section{Systematics}

Urodidae

[Korean name: So-ku-ri-na-bang-gwa]

Wockia Heinemann, 1870

Patula Bruand 1851: 50. Type species: Patula asperipunctella Bruand, 1851, by monotypy. Preoccupied by Patula Held, 1837 for Mollusca.

Wockia Heinemann 1870: 102. Type species: Wockia funebrella Heinemann, 1870 , by monotypy [a junior synonym of Wockia asperipunctella (Bruand 1851) by Ragonot, 1895: ccvi].

Wockea Reutti 1898: 291. Unjustified emendation.

Wockeia Spuler 1910: 443. Unjustified emendation.

\section{Wockia koreana Sohn, new species}

[Korean name: So-ku-ri-na-bang]

$$
\text { (Figs. 1, 3-10) }
$$

Diagnosis.-Wockia koreana is most similar to Wockia asperipunctella in wing pattern (Figs. 1-2), but differs from the latter by being smaller and as follows: valva with cucullus present; saccular process and cornuti absent; corpus bursae elliptical; a pair of spinelike signa present; and appendix bursae absent. In $W$. asperipunctella, the valva lacks a cucullus; saccular process and cornuti present; corpus bursae elongate; a pair of signa shaped as spinulated cones; and appendix bursae present.

Description.-Head: Vertex pale brown or dark brownish grey; frontoclypeus brownish grey. Labial palpus upcurved to near middle of frontoclypeus, bluntly pointed terminally, length ratio 1:2:2.5 (from base to distal end); outer surface of 1st segment with brownish white scales; 2nd segment with white-tipped brownish grey scales on basal $2 / 3$, dark brown scales on terminal $1 / 3$ ventrally; $3 \mathrm{rd}$ segment brownish white dorsally, dark brown ventrally. Scape wider in male than in female (Figs. 3-4), pale brown dorsally and dark brown ventrally; 1 st to 8th flagellomeres wider in male than female.

Thorax: Tegula dark grayish brown in female, pale brown on basal half and dark brown on distal half in male. Patagium and mesonotum dark grayish 


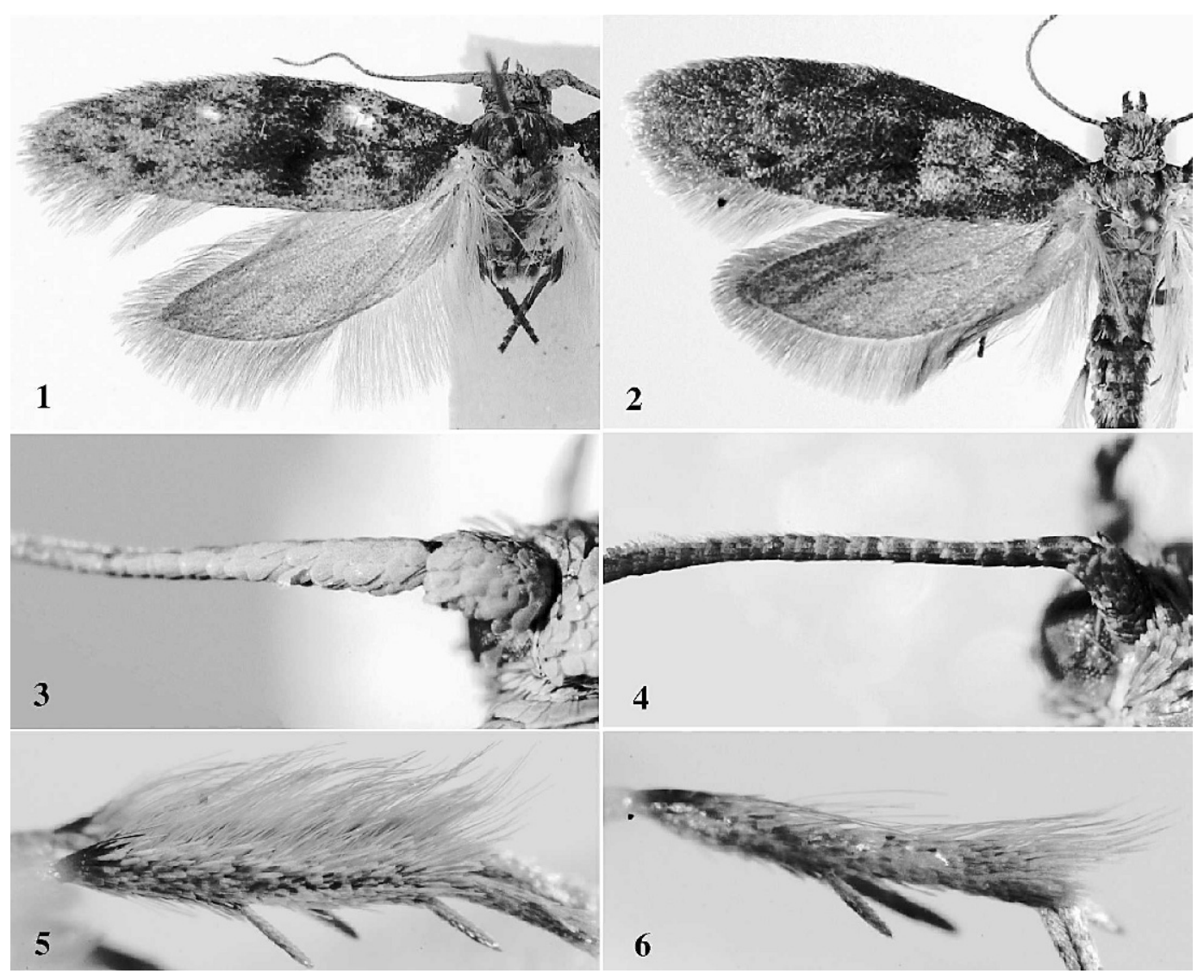

Figs. 1-6. Adults of Wockia. 1-2, Imagos. Wockia koreana, holotype, male. 2, W. asperipunctella, male. 3-4, Antennal bases of W. koreana. 3, Male. 4, Female. 5-6, Hind tibiae of W. koreana. 5, Male. 6 , Female.

brown. Legs dark brown mixed with pale brown scales; hind tibia with a long, dense tuft in male; tuft shorter in female (Figs. 5-6). Forewing (Fig. 1) length $13.3-15.1 \mathrm{~mm}(\mathrm{n}=7)$, narrowly elliptical, bluntly pointed at apex, gray, sparsely mixed with dark brown scales; an oblique, broadly suffused, dark brown band and black streak with erect scales present at about $1 / 3$; base suffused with dark-brown scales and with two black spots; outer margin mottled, including two black spots; costa broadly arched; $\mathrm{R}_{1}$ arising from radius near midlength, $\mathrm{R}_{2}-\mathrm{R}_{5}$ arising from accessory cell on anterodistal end of discal cell; $\mathbf{M}_{1}$ and $\mathbf{M}_{2}$ almost parallel except $\mathbf{M}_{2}$ slightly arched from base; $\mathrm{CuA}_{1}$ diver- gent from $\mathrm{CuA}_{2}$ near midlength. Hindwing dark gray; $\mathrm{Sc}+\mathrm{R}_{1}$ reaching margin near 2/3 length; Rs near parallel with $\mathrm{M}_{1}$; $M_{1}$ and $M_{3}$ widely separate and slightly divergent, $\mathbf{M}_{2}$ acutely arched basally, closer to $\mathrm{M}_{1}$ than to $\mathrm{M}_{3} ; \mathrm{CuA}_{1}$ and $\mathrm{CuA}_{2}$ nearly parallel; $1 \mathrm{~A}+2 \mathrm{~A}$ forked basally.

Male genitalia (Figs. 8-9): Uncus either absent or membranous, with sparsely setose, lateral lobes. Tegumen with ventrolateral margins free; vinculum Ushaped; juxta bilobed dorsoposteriorly. Valva broad, about twice length the distance between dorsal apices of vinculum, triangular at base, deeply dissected distally, forming four lobes; costal lobe digitiform; cucullar lobe spatulate; sac- 

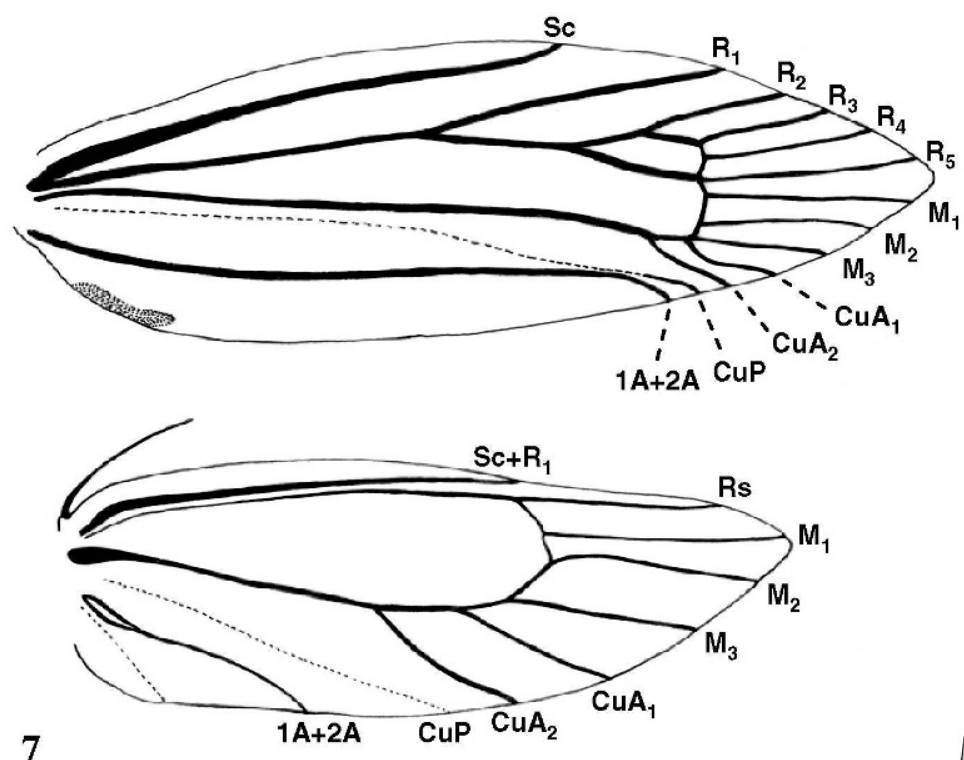

\section{7}

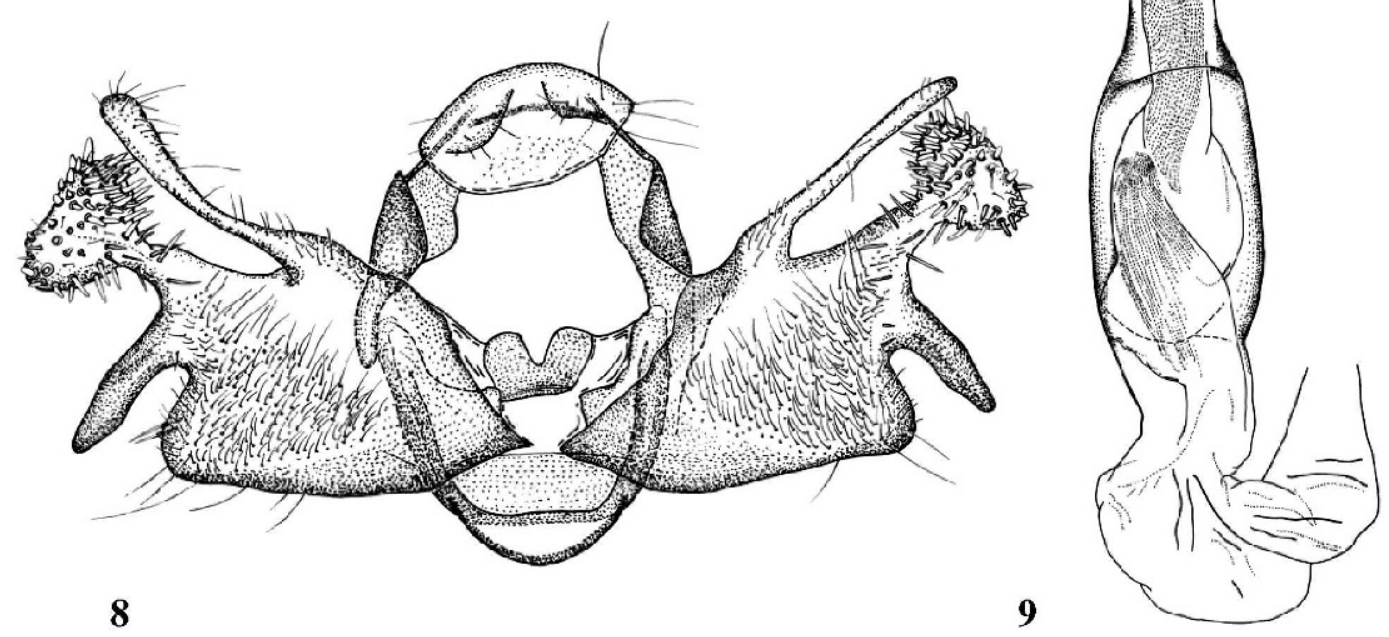

Figs. 7-9. Wing venation and male genitalia of Wockia koreana. 7, Wing venation. 8, Male genital capsule. 9, Aedeagus.

cular lobe triangular at distal end; dentiform, sclerotized process present between saccular lobe and cucullar neck; inner surface of valva densely setose. Aedeagus about 1/3 length of valva, weakly sclerotized distally; vesica finely pleated longitudinally.

Female genitalia (Fig. 10): Papillae anales lobelike, setose terminally (miss- ing in paratype); ovipositor tubular, telescopic. Apophyses posteriores twice as long as apophyses anteriores. Ostium bursae nearly as wide as ductus bursae from anterior to posterior ends. Lamella antevaginalis emarginate medially, pleated laterally. Ductus bursae nearly as long as ovipositor, flattened, slightly enlarged posteriorly, strongly sclerotized, with 


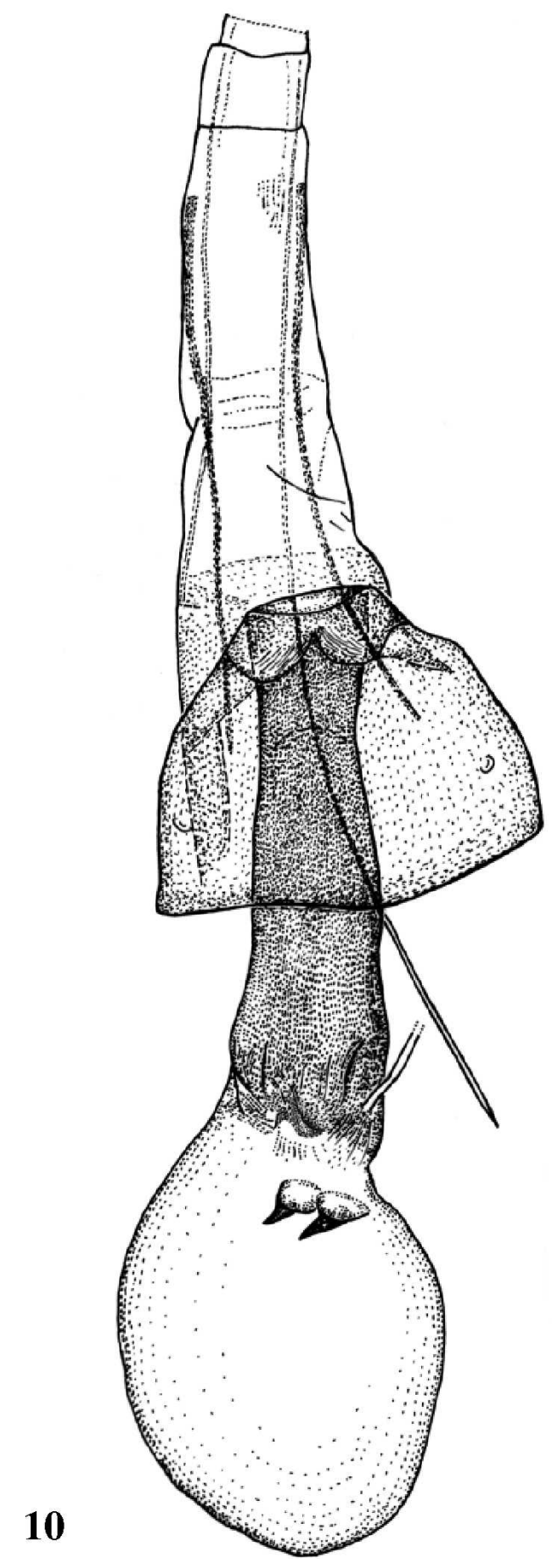

Fig. 10. Female genitalia of Wockia koreana (papillae anales missing). weak wrinkles and a deep pit near anterior end; inception of ductus seminalis near anterior end of ductus bursae. Corpus bursae slightly elliptical with a pair of conical signa.

Holotype.- $\hat{o}$, "KOREA, Gangwon Province, Hwacheon, July 2 1985, coll. K. T. Park;" "[genitalia slide no.] 1396." Deposited in Department of Plant Medicine, Chungbuk National University [CBNU], Cheongju, Korea.

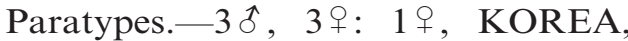
Gyonggi Province, Gwangreung, August 7 1986, coll. K. T. Park, SJC-469; 1 ô 1 우, the same locality as above, August 13 1986, coll. K. T. Park \& U. Park, SJC472( 8$) ; 1$ o (larva), the same locality as above, August 4 1988, coll. K. T. Park, SJC-468; 1 , , ditto, reared from Salix pseudo-lasiogyne Lev., August 25 2000, coll. J. C. Sohn, August 262000 (pupation), August 302000 (adult emergence), SJC-116; $1 \hat{\jmath}$, KOREA, Gyonggi Province, Mt. Soyo-san, August 5 1996, coll. Y. Bae, M. Paek, B. Lee \& N. An, SJC471. Three deposited in CBNU; three deposited in the National Museum of Natural History, Smithsonian Institution, Washington, DC, USA [USNM].

Distribution.- South Korea (Gyonggi, Gangwon and Jeonnam provinces).

Host plant.-Salix pseudo-lasiogyne Lev. (Salicaceae). Larva feeds on leaves externally.

Remarks.-We found a second new species of Wockia in Korea, represented by a single female from Seoul. We postpone its description until a male specimen is discovered. Given these two records from Korea, we think it is highly likely that Wockia species will be found in other East Asian countries as well.

Etymology.-The species name is derived from the country of collection.

\section{ACKNOWLEDGMENTS}

We express our gratitude to Charles Mitter, University of Maryland, for 
revision of the manuscript, Kyu-Tek Park, Gangwon National University, for the loan of specimens and genitalia slides, and Jon Lewis, Systematic Entomology Laboratory, U.S. Department of Agriculture, for assistance with photography.

\section{Literature Cited}

Bruand, T. 1851. Catalogue systematique et synonymique des Lépidoptères du Département du Doubs. Tineides. Mémoirs de la Société d'emulation du Doubs (1) 3(3): 23-58.

Clark, J. F. C. 1941. The preparation of slides of the genitalia of Lepidoptera. Bulletin of the Brooklyn Entomological Society 36: 149-161.

Common, I. F. B. 1990. Moths of Australia. E. J. Brill and Melbourne University Press, vi $+535 \mathrm{pp}$.

Fänger, H. 1999. Comparative morphology of tergal phragmata occurring in the dorsal thoracoabdominal junction of ditrysian Lepidoptera (Insecta). Zoomorphology 119(3): 163-183.

Forbes, W. T. M. 1948. Lepidoptera of New York and Neighboring States. Part II. Memoirs of the Conell University Agricultural Experiment Station 274: 128-175.

Heinemann, H. 1870. Die Schmetterlinge Deutschlands und der Schweiz 2(1): 388.

Heppner, J. B. 1997. Wockia asperipunctella in North America (Lepidoptera: Urodidae: Galacticinae). Holarctic Lepidoptera 4: 73-74. . 1998. Classification of Lepidoptera, Part 1. Introduction. Holarctic Lepidoptera 5(Suppl. 1): $1-148$.

Herrich-Schäffer, G. A. W. 1850-1858. Sammlung neuer oder wenig bekannter aussereuropäischer Schmetterlinge. Vol. 1.84 pp. $96+24$ pls.

Klots, A. B. 1970. Lepidoptera, pp. 115-130. In Tuxen, S. L., ed. Taxonomist's glossary of Genitalia in Insects. Munksgaard.

Kristensen, N. P. and A. W. Skalski. 1998. 2. Phylogeny and Palaeontology, pp. 7-25. In Kristensen, N. P., ed. Lepidoptera, Moths and Butterflies Vol. 1: Evolution, Systematics and Biogeography. Handbook of Zoology 4(35). Walter de Gruyter.
Kyrki, J. 1984. The Yponomeutoidea: A reassessment of the superfamily and its suprageneric groups (Lepidoptera). Entomologica Scandinavica 15: 71-84.

. 1988. The systematic position of Wockia Heinemann, 1870, and related genera (Lepidoptera: Ditrysia: Yponomeutidae auct.). Nota Lepidopterologica 11(1): 45-69.

- 1990. Tentative reclassification of holarctic Yponomeutoidea (Lepidoptera). Nota Lepidopterologica 13: 23-42.

Leraut, P. 1980. Liste systématique et synonymique des lépidoptères de France, Belgique et Corse. Alexanor and Bulletin de la Société Entomologique France, Supplement, $1-334$.

Lower, O. B. 1899. Descriptions of new Australian Lepidoptera. Proceedings of the Linnean Society of New South Wales 24: 83-116.

Meyrick, E. 1913. Hyponomeutidae, pp. 65-176. In Meyrick, E., ed. Exotic Microlepidoptera. Vol. 1 (1912-1916).

Minet, J. 1986. Ébauche d'une classification modern de l'ordre des Lépidoptères. Alexanor 14: 291-313.

Nielsen, E. S. 1989. Phylogeny of major lepidopteran groups, pp. 281-294. In Ferholm, B., K. Bremer, and H. Joernvall, eds. The Hierarchy of Life. Elsevier.

Ragonot, E.-L. 1895. Communication. Annales de la Société Entomologique de France 63: ccvi-ccvii.

Reutti, C. 1898. Übersicht der Lepidopteren-Fauna des Grossherzogtums Baden (und der anstossenden Länder). 2. Verhandlungen Naturwissenschaftlicher Verein in Karlsruhe 12: i-xii, $1-361$.

Scoble, M. J. 1992. The Lepidoptera: Form, Function and Diversity. The Natural History Museum and Oxford University Press, 404 pp.

Spuler, A. 1910. Die Schmetterlinge Europas. 2. Stuttgart, $523 \mathrm{pp}$.

Zagulyaev, A. K. 1989. Plutellidae, pp. 473-522. In Medvedev, G. S., ed. Keys to the Insects of the European Part of the USSR. IV, Part 2. Oxonian Press. 